\title{
OPTIMIZATION OF OPERATING CONDITIONS OF ALUMINUM MELT REFINING PROCESS IN LABORATORY CONDITIONS
}

\author{
${ }^{1}$ Ladislav SOCHA, ${ }^{1}$ Karel GRYC, ${ }^{1}$ Jana SVIŽELOVÁ, ${ }^{2}$ Tomáš PRÁŠIL, ${ }^{2}$ Roman POSPÍŠIL, \\ ${ }^{2}$ Martin GRÁF \\ ${ }^{1}$ Institute of Technology and Business in České Budějovice, České Budějovice, Czech Republic, EU, \\ socha@mail.vstecb.cz, gryc@mail.vstecb.cz, svizelova@mail.vstecb.cz \\ ${ }^{2}$ MOTOR JIKOV Slévárna (Foundry) a.s., Die-casting Division, České Budějovice, Czech Republic, EU, \\ TPrasil@migroup.cz, RPospisil@misl.cz, MGraf@misl.cz
}

https://doi.org/10.37904/metal.2021.4257

\begin{abstract}
Many industries desire to use aluminum alloys due to their properties, including low weight, good strength properties, corrosion resistance and good castability. This growing popularity of aluminum alloys increases the requirements for their purity and hence any associated structural defects and degradation of casting properties. Degraded properties of aluminum alloy castings are associated with, among other things, the presence of dissolved hydrogen. Mostly, hydrogen is removed from aluminum alloys by the FDU refining unit. Several variable parameters, which provide room for optimizing the process and increasing the degassing efficiency, characterize this technology. This paper focuses on research and optimization of refining technology at the FDU. Experiments using a physical model were performed to describe the effect of defined operating parameters on degassing intensity. Based on the experiments, combinations of operating parameters selected for testing in operational conditions were proposed.
\end{abstract}

Keywords: Aluminum, physical modelling, refinement process, FDU, metallurgy

\section{INTRODUCTION}

Various phases (e.g. metal and non-metal inclusions, gases) are produced in the manufacture and processing of aluminum alloys; these phases degrade the casting properties. Hydrogen is a harmful gas that has a negative impact on the properties of castings made of aluminum and its alloys [1-4]. In the course of solidification, hydrogen is excluded from the metal and forms gaseous $\mathrm{H}_{2}$ molecules that cause porosity in castings [5].

The adverse effect of hydrogen is caused by its different solubility in the liquid and solid phase. This is demonstrated by temperature dependence of hydrogen solubility in aluminum and its alloys illustrated in Figure 1 [2-4]. As can be seen, hydrogen solubility in the liquid phase is relatively high, and as the temperature decreases, its solubility is considerably reduced. A similar trend can also be observed in the case of hydrogen solubility in aluminum alloys [6]. When the hydrogen content in the metal exceeds the value corresponding to its solubility, hydrogen starts escaping from the metal by diffusion or in the form of gaseous bubbles, often leading to defects in the castings and degradation of their quality.

Introduction of an inert gas into the molten mass and hydrogen diffusion into the inert gas bubbles is one of the most common ways of removing hydrogen from aluminum alloys at foundry plants. The theoretical basis of this refining process was described by authors of the studies [2-4]. Under operating conditions, this method is often implemented using an FDU (Foundry Degassing Unit) refining system [7]. The FDU unit is composed of several components. Components that have an immediate impact on refining of the molten mass include an impeller with a hollow shaft and a baffle (see Figure 2). The shaft and the impeller are used to introduce an inert gas (nitrogen, argon) into the molten mass; through the action of rotation of the impeller, thegas is broken into bubbles. Subsequently, hydrogen dissolved in the alloy diffuses into the bubbles. Additionally, the 
impeller has an impact on the flow in the pan and facilitates hydrogen transport to the phase interface with the inert gas bubble [8]. The very small gas bubbles and intensive agitation of the molten mass ensure rapid and efficient degassing, removal of impurities and reduction of the content of non-metal inclusions [2-4]. The refining principle at FDU unit is illustrated in Figure 3. TheFDU unit is characterised by a variability of process parameters; by changing these parameters, it is possible to affect the course and efficiency of the refining process [9-14]. These parameters include the impeller type, rotation frequency, working height, inert gas flow rate and the number of baffles.

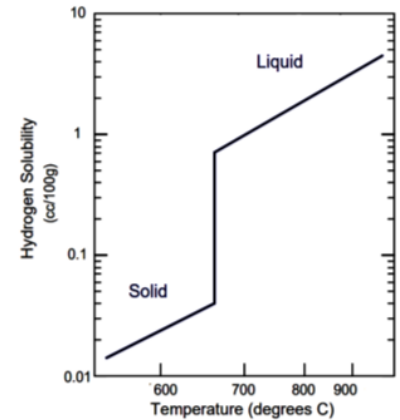

Figure 1 Hydrogen solubility in molten aluminum [1-4]

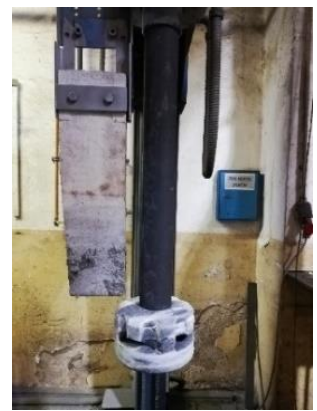

Figure 2 Illustration of graphite impeller and baffle

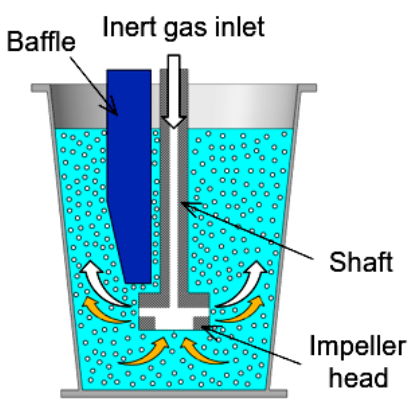

Figure 3 Principle of refinement process by the FDU unit [7]

This paper explored degassing at the FDU unit used in the conditions of the Die-casting Division at MOTOR JIKOV Slévárna (Foundry) a.s. as a refining technology of aluminum alloys in the process of high-pressure and low-pressure casting. The objective of the research was to optimise selected operating parameters with respect to increasing the efficiency of degassing at the FDU unit. The research was done through physical modelling whose results were used to propose optimised FDU parameters intended for testing under operating conditions.

\section{DESCRIPTION OF PHYSICAL MODEL AND EXPERIMENTAL METHODOLOGY}

A water-based physical model of the refining system was constructed for the purpose of physical modelling of aluminum alloy degassing at the Environmental Research Department of the Institute of Technology and Business in České Budějovice (see Figure 4). The physical model was constructed according to the FDU unit used at MOTOR JIKOV Slévárna (Foundry) a.s. Essential components of the system include a plexiglass vessel (refining pan model), graphite impeller, baffle and optic probes to measure oxygen concentration in water. In order to respect geometric conformity of the model and the work, the model vessel was manufactured in the 1:1 ratio with respect to the operating pan. The impeller and the baffle (see Figure 2 and Figure 5) are standard components used in operating conditions.
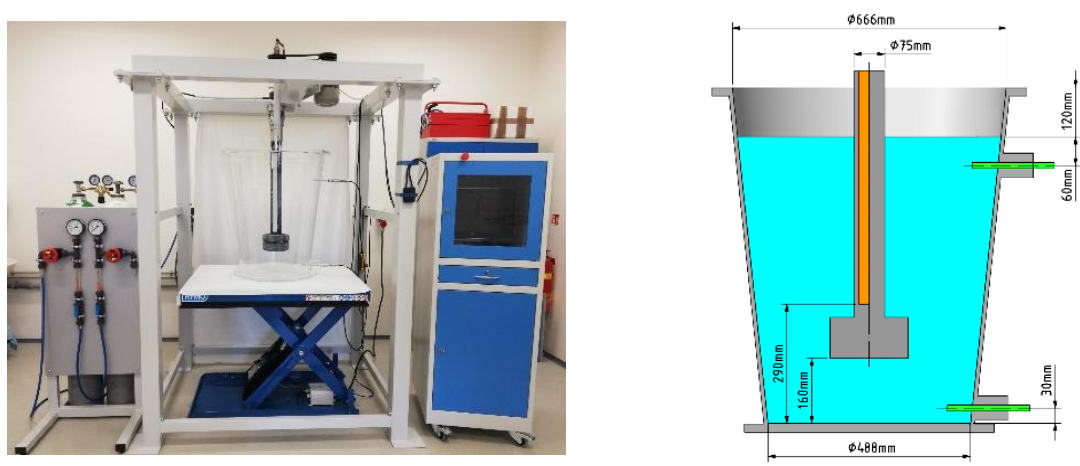

Figure 4 Illustration of the physical model, components layout and base dimensions of the model assembly

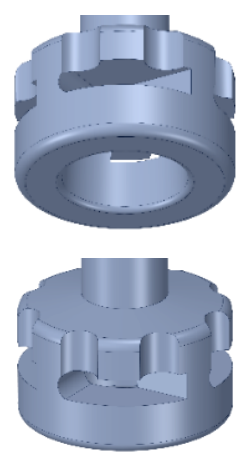

Figure 5 Impeller design 
The principle of physical modelling was aimed at capturing molten mass degassing intensity and analysing how the harmful gas content decreases with various parameter values under laboratory conditions. For this purpose, it was necessary to choose appropriate media that would preserve dynamic similarity between the model and the actual work. Therefore, molten aluminum was replaced with water and the hydrogen to be removed was replaced with oxygen. To give a better idea, basic characteristics of molten aluminum and model media are presented in Table 1.

Table 1 Properties of molten aluminum and model media

\begin{tabular}{|l|c|c|c|}
\hline \multicolumn{1}{|c|}{ Parameter } & Aluminum & Water & Oxygen \\
\hline Temperature $\left({ }^{\circ} \mathrm{C}\right)$ & 750 & 20 & 20 \\
\hline Density $\left(\mathrm{kg} \cdot \mathrm{m}^{-3}\right)$ & 2345 & 998.2 & 1.299 \\
\hline Dynamic viscosity $\left(\mathrm{kg} \cdot \mathrm{m}^{-1} \cdot \mathrm{s}^{-1}\right)$ & $1.200 \cdot 10^{-3}$ & $1.003 \cdot 10^{-3}$ & $0.019 \cdot 10^{-3}$ \\
\hline Kinematic viscosity $\left(\mathrm{m}^{2} \cdot \mathrm{s}^{-1}\right)$ & $0.51 \cdot 10^{-6}$ & $1.01 \cdot 10^{-6}$ & $14.77 \cdot 10^{-6}$ \\
\hline
\end{tabular}

Table 2 presents operating conditions of the molten aluminum refining process; these conditions were used as a basis to determine the physical modelling conditions for the studied impeller type. Based on these conditions, pilot physical modelling was performed to verify the methodology. Subsequently, laboratory experiments using the physical model were defined and carried out in order to describe the effects of key refining process variables on molten mass degassing intensity and identify an optimum combination of these parameters for testing under operating conditions. The actual parameters and conditions of individual experiments using the FDU physical model were designed in cooperation with technologists of the Die-casting Division of MOTOR JIKOV Slévárna (Foundry) a.s. Basic parameters taken into account when defining the model variants included: impeller type, working height, number of baffles, rotation frequency, and the inert gas (Ar) flow rate.

Table 2 Comparison of operating conditions with the physical model

\begin{tabular}{|l|l|l|}
\hline \multicolumn{1}{|c|}{ Parameter } & \multicolumn{1}{|c|}{ Operating conditions } & \multicolumn{1}{c|}{ Physical model conditions } \\
\hline Working height of impeller & $160 \mathrm{~mm}$ & $160 \mathrm{~mm}$ \\
\hline Number of baffles & 1 & 1 \\
\hline Refinement time & $180 \mathrm{~s}$ & $180 \mathrm{~s}$ \\
\hline Rotation frequency & $350 \mathrm{rpm}$ & $350 \mathrm{rpm}$ \\
\hline Inert gas type & Nitrogen & Argon \\
\hline Inert gas flow rate & $17 \mathrm{Nl} \cdot \mathrm{min}^{-1}$ & $17 \mathrm{NI} \cdot \mathrm{min}^{-1}$ \\
\hline
\end{tabular}

In the first phase of research, attention was focused on the effect of the rotation frequency and inert gas flow rate. Variants with changing values of these parameters and their combinations, feasible for actual operation, were defined in order to describe the effect of rotation frequency of the impeller and argon flow rate. In total, 30 experiment variants were defined and performed for the studied impeller type while preserving the working height and using one baffle. The parameters of these experiments are shown in Table 3.

Table 3 Settings of modelled variants (working height: $160 \mathrm{~mm}$, baffles: $1 \mathrm{pc}$ )

\begin{tabular}{|c|c|c|c|c|c|c|c|c|c|c|c|c|c|c|c|c|c|c|c|c|c|c|c|c|c|c|c|c|c|c|}
\hline $\begin{array}{c}\text { Rotation } \\
\text { frequency (rpm) }\end{array}$ & \multicolumn{9}{|c|}{300} & \multicolumn{3}{|c|}{325} & \multicolumn{3}{|c|}{375} & \multicolumn{3}{|c|}{400} & \multicolumn{3}{c|}{425} \\
\hline $\begin{array}{c}\text { Argon flow rate } \\
(\text { Nl.min-1) }\end{array}$ & 13 & 15 & 17 & 19 & 21 & 13 & 15 & 17 & 19 & 21 & 13 & 15 & 17 & 19 & 21 & 13 & 15 & 17 & 19 & 21 & 13 & 15 & 17 & 19 & 21 & 13 & 15 & 17 & 19 & 21 \\
\hline
\end{tabular}




\section{RESULTS AND DISCUSSION}

Experiments performed using the physical model provided curves of oxygen concentration decrease in water. To give an idea of the course, efficiency and characteristics of the processes, results representing oxygen concentration decrease during refining under different flow rates of the inert gas and rotation frequencies were chosen according to the variants proposed in Table 3. In order to demonstrate the effect of the rotation frequency, Figure 6a shows concentration curves measured under constant argon flow rate of $17 \mathrm{Nl} \cdot \mathrm{min}^{-1}$ and variable rotation frequency values from 300 to $425 \mathrm{rpm}$. Clearly, when the argon flow rate is preserved and the rotation frequency increases, the elimination of oxygen from water becomes faster. A similar effect is achieved when the argon flow rate is increased while preserving the same rotation frequency value as can be seen in Figure $\mathbf{6 b}$. To give an idea of the flow characteristics in the physical model with changing parameter values, Figure 7 shows selected photographs of the physical model made during the degassing process.

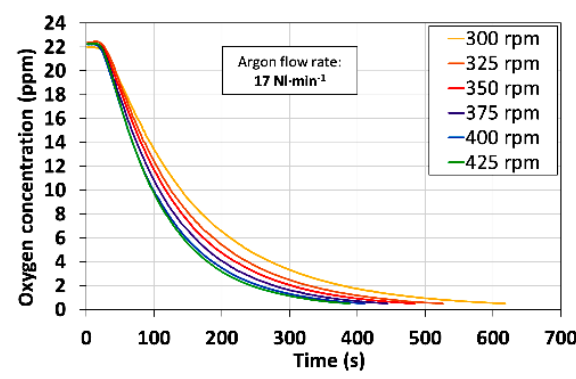

a) Effect of rotation frequency

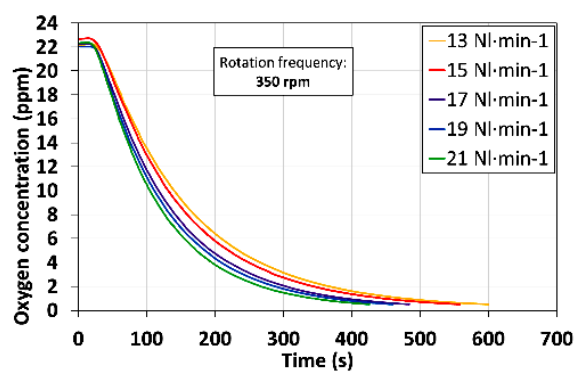

b) Effect of Ar flow rate

Figure 6 Illustrative results measured using the physical model - concentration curves

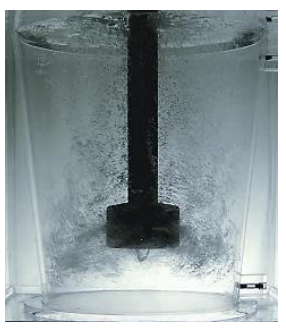

a) Parameters: $13 \mathrm{NI} \cdot \mathrm{min}^{-1}, 300 \mathrm{rpm}$

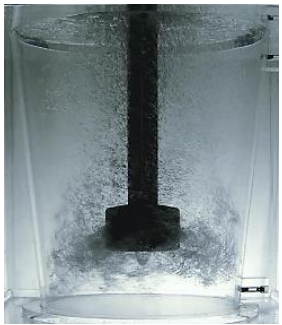

d) Parameters: $17 \mathrm{Nl} \cdot \mathrm{min}^{-1}, 300 \mathrm{rpm}$

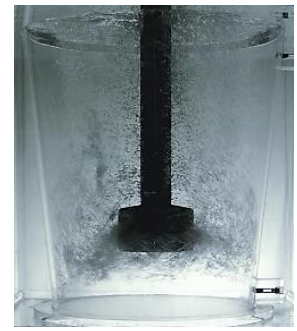

g) Parameters: $21 \mathrm{Nl} \cdot \mathrm{min}^{-1}, 300 \mathrm{rpm}$

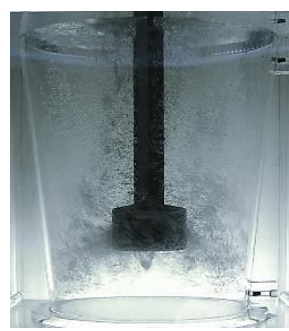

b) Parameters: $13 \mathrm{NI} \cdot \mathrm{min}^{-1}, 350 \mathrm{rpm}$

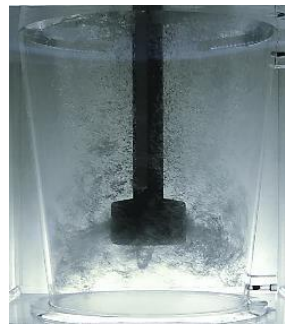

e) Parameters: $17 \mathrm{NI} \cdot \mathrm{min}^{-1}, 350 \mathrm{rpm}$

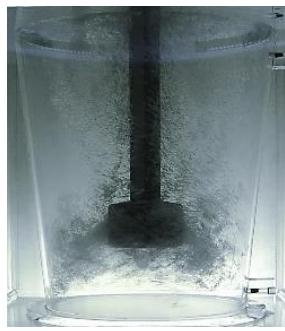

h) Parameters: $21 \mathrm{NI} \cdot \mathrm{min}^{-1}, 350 \mathrm{rpm}$

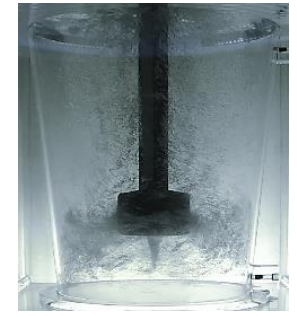

c) Parameters: $13 \mathrm{NI} \cdot \mathrm{min}^{-1}, 400 \mathrm{rpm}$

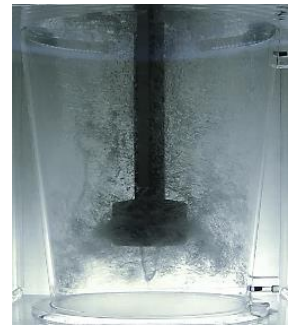

f) Parameters: $17 \mathrm{NI} \cdot \mathrm{min}^{-1}, 400 \mathrm{rpm}$

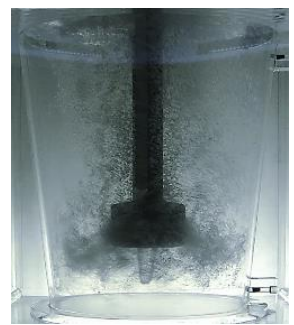

i) Parameters: $21 \mathrm{NI} \cdot \mathrm{min}^{-1}, 400 \mathrm{rpm}$

Figure 7 Visualization of flow characteristics in the physical model 
The presented results provide an idea of the impact of individual parameters on oxygen concentration decrease in water. Different settings of the process parameters achieve different degassing intensities. In order to assess degassing intensity using various combinations of the studied parameters, individual variants were plotted in Figure8. This graph shows oxygen concentration achieved after $180 \mathrm{~s}$ of degassing, which is the duration of refining at the FDU unit under operating conditions (see Table 2). The lower the concentration achieved in the experiment, the more intensive degassing process is assumed. The graph also includes variant (16) with standard parameters used under operating conditions (350 rpm, $17 \mathrm{NI} \cdot \mathrm{min}^{-1}$ ), resulting in oxygen concentration decrease from $22 \mathrm{ppm}$ to $5.65 \mathrm{ppm}$ after $180 \mathrm{~s}$.

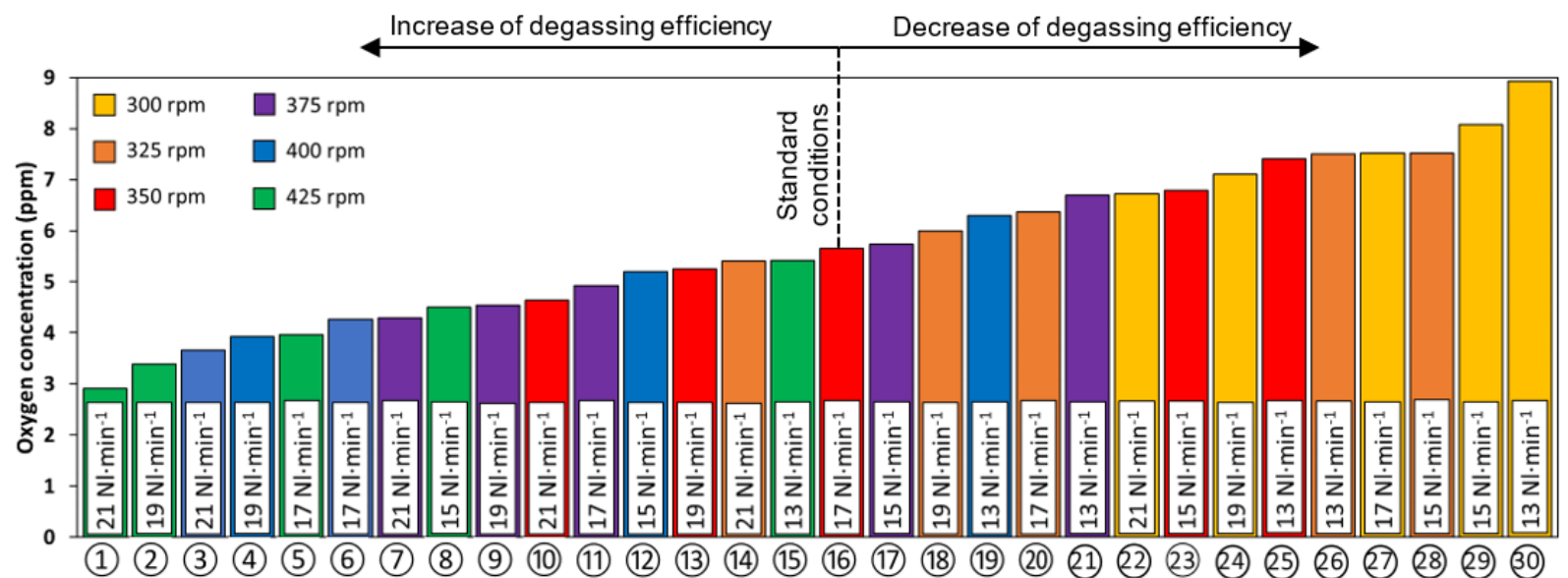

Figure 8 Quantitative efficiency values of defined experiments ordered according to concentration reached after $180 \mathrm{~s}$ of the degassing process

The graph indicates three routes that could theoretically lead to higher degassing intensity within the determined time interval of $180 \mathrm{~s}$. The first option consists in increasing the impeller rotation frequency while preserving the inert gas flow rate $17 \mathrm{NI} \cdot \mathrm{min}^{-1}$. When the rotation frequency was increased from $350 \mathrm{rpm}$ (variant(16) to $375 \mathrm{rpm}$ (variant(11)),oxygen concentration decreased by approx. $0.72 \mathrm{ppm}$. Upon a further increase of the rotation frequency to $400 \mathrm{rpm}$ (variant(6)),oxygen concentration decreased by $1.38 \mathrm{ppm}$ compared to the operating variant (16). An additional increase of rotation frequency to $425 \mathrm{rpm}$ (variant(5) had no considerable effect in terms of a further decrease of oxygen concentration. The second option consists in increasing the inert gas flow rate while preserving a constant rotation frequency of $350 \mathrm{rpm}$. However, this option seems less efficient. When the flow rate was increased from $17 \mathrm{Nl} \cdot \mathrm{min}^{-1}$ (variant(16)) to the highest value of $21 \mathrm{Nl} \cdot \mathrm{min}^{-1}$ (variant(10), oxygen concentration was decreased by $1.01 \mathrm{ppm}$ compared to the operating variant. A similar result was achieved after increasing the rotation frequency to $375 \mathrm{rpm}$ and argon flow rate to $19 \mathrm{Nl} \cdot \mathrm{min}^{-1}$ (variant (9)) at the same time, which is the third option. A combined effect of increasing the argon flow rate and the rotation frequency started to be more noticeable only with variant (4) with $400 \mathrm{rpm}$ and 19 $\mathrm{NI} \cdot \mathrm{min}^{-1}$. Despite that, the combined change of the parameters did not provide a considerable decrease of the concentration below the value of variant (6) with $400 \mathrm{rpm}$ and $17 \mathrm{NI} \cdot \mathrm{min}^{-1}$.

\section{CONCLUSIONS}

An experimental study of the molten aluminum degassing process at the FDU unit was undertaken at the Environmental Research Department of the Institute of Technology and Business in České Budějovice using a physical model. The defined conclusions can be summarized as follows:

$\checkmark \quad$ A physical model of the FDU refining unit was constructed; the model was made according to the FDU unit used at the Die-casting Division of MOTOR JIKOV Slévárna (Foundry) a.s. 
$\checkmark \quad$ Based on operating conditions of the FDU unit, basic parameters of the physical model were defined and experiments were designed aimed at verifying the impact of changes in the impeller rotation frequency and in the inert gas flow rate on oxygen concentration decrease in water. In total, 30 experiment variants were proposed and implemented.

$\checkmark \quad$ An increase of the rotation frequency while maintaining a constant inert gas flow rate was manifested by an increased oxygen removal from water. It is recommended to increase the rotation frequency up to $400 \mathrm{rpm}$. A further increase above this value provides no added considerable effect.

$\checkmark \quad$ An increase of the inert gas flow rate while maintaining a constant rotation frequency of the impeller accelerates oxygen removal from water. However, the effect is not as distinct as when the impeller's rotation frequency is increased.

$\checkmark \quad$ Oxygen removal from water can also be accelerated through a combined change of the rotation frequency and inert gas flow rate. A positive impact of these parameters in terms of an oxygen concentration decrease was apparent only at $400 \mathrm{rpm}$ and at inert gas flow rate of $19 \mathrm{Nl} \cdot \mathrm{min}^{-1}$. However, similar concentrations can be achieved merely by changing the rotation frequency of the impeller.

$\checkmark \quad$ Based on the achieved results, variants with rotation frequencies 350 to $400 \mathrm{rpm}$ and inert gas flow rates 17 and $19 \mathrm{Nl} \cdot \mathrm{min}^{-1}$ are recommended for testing under operating conditions.

\section{ACKNOWLEDGEMENTS}

The paper was prepared under the support of the Technology Agency of the Czech Republic within the scope of the EPSILON programme, as part of projects Reg. No. TH04010449 "Research and development of refining technologies for increasing of quality of aluminum alloys for high-performance quality castings".

\section{REFERENCES}

[1] MICHNA, Š, LUKÁČ, I. et al. Aluminum materials and technologies from A to Z. Prešov: Adin s.r.o., 2007, p. 700. ISBN 80-890-4188-4.

[2] SIGWORTH, G.K. Gas fluxing of molten aluminum. GRANDFIELD, J., ESKIN D. Essential readings in light metals. Springer International Publishing, 2016, pp. 226-233. ISBN 978-3-319-48576-8.

[3] SIGWORTH, G.K. A scientific basis for degassing aluminum. In: 91. AFS annual meeting. 1987, pp. 73-78. ISBN 0-87433-106-4.

[4] SIGWORTH, G.K., WILLIAMS, E.M., CHESONIS, D.C. Gas fluxing of molten aluminum: An overview. EYOUNG, D.H. Light metals 2008. New Orleans, 2008. ISBN 978-0-87339-710-0.

[5] VOJTĚCH, D. Metallic materials. 1. ed. Prague: University of Chemistry and Technology, 2006. ISBN 80-7080-600-1.

[6] BOLIBRUCHOVÁ, D., PASTRIČÁK, R. Foundry metallurgy of non-ferrous metals. Žilina: EDIS, 2018. ISBN 97880-554-1463-8.

[7] Melt treatment products for aluminum, copper, magnesium and zinc alloys. Vesuvius [online]. 2021 [viewed: 2021-04-16]. Available from: https://www.vesuvius.com/en/our-solutions/en-za/foundry/non-ferrous-foundry/melttreatment.html.

[8] MYSLIVEC, T. Physico-chemical bases of steel industry. Prague: SNTL, 1971.

[9] SATERNUS, M., MERDER, T. Numerical and physical modelling of aluminumrefining process conducted in URO200 reactor. Solid State Phenomena. 2012, vol. 191, pp. 3-12. ISSN 1662-9779. DOI Available from: https://doi.org/10.4028/www.scientific.net/SSP.191.3.

[10] GÓMEZ, E.R., ZENIT, R., GONZÁLEZ-RIVERA, C.G., TRÁPAGA, G., RAMÍREZ-ARGÁEZ, M.A. Physical modeling of fluid flow in ladles of aluminum equipped with impeller and gas purging for degassing. Metallurgical and Materials Transactions B. 2013, vol. 44, no. 4, pp.974-983. ISSN 1073-5615. Available from: https://doi.org/10.1007/s11663013-9845-5. 
[11] HERNÁNDEZ-HERNÁNDEZ, M., CAMACHO-MARTÍNEZ, J.L., GONZÁLEZ-RIVERA, C., et al. Impeller design assisted by physical modeling and pilot plant trials. Journal of Materials Processing Technology. [online]. 2016, vol. 236, pp. 1-8. Available from: https://doi.org/10.1016/.j.jmatprotec.2016.04.031.

[12] SVIŽELOVÁ, J., TKADLEČKOVÁ, M., MICHALEK, K., WALEK, J. Development of a monitoring method of hydrogen removal from aluminummelt using numerical modelling. In: METAL 2019: 28th International Conference on Metallurgy and Materials. Ostrava: Tanger, 2019, pp. 1715-1720. ISBN 978-80-87294-92-5.

[13] LICHÝ, P., BAJEROVÁ, M., KROUPOVÁ, I., OBZINA, T. Refining aluminum-alloy melts with graphite rotors. Materiali in Technologije. [online]. 2020, vol. 54, no. 2, pp. 263-265. Available from: https://doi.org/10.17222/mit.2019.147.ISSN 1580-2949.

[14] MICHALEK, K., TKADLECKOVA, M., SOCHA, L., GRYC, K., SATERNUS, M., PIEPRZYCA, J., MERDER, T. Physical modelling of degassing process by blowing of inert gas. Archives of Metallurgy and Materials. [online]. 2018, vol. 63, no. 2, pp. 987-992. Available from: https://doi.org/10.24425/122432. ISSN 1733-3490. 